Plant Production Science
Available online at http://zjar.journals.ekb.eg
http:/www.journals.zu.edu.eg/journalDisplay.aspx?Journalld=1\&queryType=Master

\title{
EFFECT OF SOME EDIBLE COATING MATERIALS ON QUALITY AND POSTHARVEST ROTS OF CHERRY TOMATO FRUITS DURING COLD STORAGE
}

\author{
Omaima O. Mohammed $^{1 *}$, M.B. Azzazy ${ }^{2}$ and S.E.A. Badawe ${ }^{3}$ \\ 1. Post Harvest and Handling of Veg. Crops Dept., Hort. Res. Inst., ARC, Giza, Egypt \\ 2. Hort. Products Technol. Dept., Food Technol. Res. Inst., ARC, Giza, Egypt \\ 3. Dept. Veg. Diseases, Plant Pathol. Res. Inst., ARC, Giza, Egypt
}

Received: 29/11/2020 ; Accepted: 27/12/2020

\begin{abstract}
This study was carried out during two successive seasons of 2018 and 2019 on cherry tomato F1 hybrid Cherubino which harvested at turning stage (25\% red colour) from a private Farm at El Salhia El Gadeda District, Sharkia Governorate, Egypt. The aim of this work was to study the effect of dipping the fruits in solutions of some edible materials, (arabic gum, cellulose, pectin, xanthan) on maintaining quality and storability of cherry tomato fruits and postharvest rots during storage at $13^{\circ} \mathrm{C}$ and $90-95 \%$ relative humidity for 40 days. Weight loss percentage, general appearance, fruit firmness, TSS, titratable acidity, lycopene fruit content, $\mathrm{pH}$ values, vitamin $\mathrm{C}$, dry matter and sensory evaluation as well as postharvest rots for fruits treated with arabic gum at $5 \%$ or $10 \%$ and pectin at $2 \%$, were slightly affected by the prolonging of the storage period comparing with untreated fruits and other treatments. General appearance, fruit firmness, titratable acidity, $\mathrm{pH}$ values, vitamin $\mathrm{C}$ and dry matter (\%) were decreased as the storage period prolonged, whereas weight loss percentage, TSS and lycopene fruit content were increased. Coating cherry tomato fruits with arabic gum at 5 or $10 \%$ and pectin at $2 \%$ were the superior treatments during storage at $13^{\circ} \mathrm{C}$ and $90-95 \%$ $\mathrm{RH}$ in reducing weight loss (\%), lycopene fruit content and TSS, meanwhile maintaining general appearance, fruit firmness, titratable acidity, $\mathrm{pH}$ values, vitamin $\mathrm{C}$ and dry matter (\%). In addition, sensory evaluation showed that $10 \%$ or $5 \%$ arabic gum coating maintained the overall quality of the tomato fruit during storage, meanwhile treating cherry tomato fruits with arabic gum at $10 \%$ was the most effective treatment against fruits rots in both artificially and naturally infected fruits followed by arabic gum at $5 \%$.
\end{abstract}

Key words: Cherry tomato, edible materials, arabic gum, cellulose, pectin, xanthan, storage period.

\section{INTRODUCTION}

Tomato is one of the most popular vegetables grown in the world (Causse et al., 2003). Currently, "cherry" tomato Solanum lycopersicum Mill. var. cerasiforme (previous name Lycopersicon esculentum Mill. var. cerasiforme) became a popular vegetable and is grown in North Europe under protection (Kowalczyk and Gajc-Wolska, 2011). It is proved that daily intake of fresh or processed tomatoes by human decreases risk of chronic diseases, like cardiovascular diseases and cancer (Ilahy et al., 2011).

\footnotetext{
* Corresponding author: Tel.: +201225940181

E-mail address: knour23@yahoo.com
}

Tomato fruit is climactric in nature, having a respiratory peak during ripening due to release of ethylene (Hong $\boldsymbol{e t}$ al., 2012). Fruits are very perishable vegetable with a short shelf life and a high susceptibly to fungal disease (Nabi $\boldsymbol{e t}$ al., 2017). Common inherent postharvest problems of tomato fruits after harvesting include significant metabolic and physiological activities, quality degradation and shriveling, as well as fast physical decay and physiological senescence (El-Ramady et al., 2015).

It is necessary to use some technique treatments (Arabic gum, cellulose, pectin and 
xanthan) as postharvest treatments that conjunction with low temperature to extend shelf life, maintain quality and improved storability of tomato fruits during storage.

Edible coatings generate a modified atmosphere by creating a semi-permeable barrier against $\mathrm{O}_{2}, \quad \mathrm{CO}_{2}, \quad$ moisture, and solute movement, thus reducing respiration, water loss, and oxidation reaction rates (Ali et al., 2010). Different materials have been used as edible coatings and are commonly based on proteins, lipids, or polysaccharides (Valencia-Chamorro et al., 2010). The great benefit conferred by edible coatings is that these are natural biodegradable products (Sanchez-Gonz et al., 2011).

Arabic Gum (AG), extracted from stems of Acacia tree comprising galactose, rhamnose, arabinose and glucoronic acid (Anderson et al., 1991). When used gum arabic showed some positive results and significantly delayed maturity of cold-stored fruits (El-Anany et al., 2009). In a previous study revealed that AG not only enhanced shelf-life but also maintained postharvest quality of repine-green tomatoes for up to 20 days during storage at $20^{\circ} \mathrm{C}$ (Ali et al., 2010; Ruelas-Chacon et al., 2017).

Pectin and cellulose are polysaccharide made up of galactouronic acids and these are considered as amorphous, white coloured colloidal carbohydrate. The pectin based edible coating incorporated with oregano essential oil was found to be effective in reducing the fungal decay and also resulted in the increased antioxidant activity of tomatoes (Isela $\boldsymbol{e t} \boldsymbol{a l}$., 2016). Felix and Mahendran (2009) and Abebe et al. (2017) found that, tomato fruits coated with pectin at $3 \%$ delayed the ripening process with better fruits quality than uncoated ones, delay the change of weight loss, disease incidence, disease severity and ripening index as compared to control fruits. Moreover, coated fruits revealed higher amount of ascorbic acid, lycopene and phenolic contents.

Xanthan is one of the most extensively investigated polysaccharides. It is high in molecular weight (1-2 million) and is produced by a pure culture fermentation of a carbohydrate by naturally occurring bacterium Xanthomonas compestris (Sharma et al., 2006). Using1.4\% xanthan gum as edible coating may form a protective barrier on the surface of acerola, the ripening process of acerola can be delayed and prevented oxygen penetration. It can be prolong the preservation of acerola during 6 days at $30^{\circ} \mathrm{C}$ without any negative effects on quality of fruit (Quoc et al., 2015).

Guava fruits coated with $1 \%$ xanthan gum achieved the lowest decay percent, maintained fruit firmness, vitamin $\mathrm{C}$ and reduced weight loss (Gad and Zagzog, 2017).

Therefore, the aim of this investigation was to improve cherry tomatoes storability with high marketable quality and controlling postharvest storage rots. This may be achieved by testing the effect of some edible coating materials (Arabic gum, cellulose, pectin and xanthan) as postharvest treatments on quality attributed of cherry tomatoes fruits during storage.

\section{MATERIALS AND METHODS}

This work carried out during two successive seasons of 2018 and 2019 to study the effect of dipping cherry tomatoes fruits in solutions of some edible materials on maintaining quality and storability during cold storage. Cherry tomatoes (Solanum lycopersicum Mill. var. cerasiforme) F1 hybrid Cherubino were harvested at turning stage (25\% red colour) on $4^{\text {th }}$ and $3^{\text {rd }}$ February in the first and second seasons, respectively from a private Farm at El Salhia El Gadeda District, Sharkia Governorate, Egypt, and transported soon to the Handling Lab., Hort. Dept., Fac. Agric., Zagazig Univ., Egypt, within two hours after harvesting. Fruits of the same size $(20-25 \mathrm{~mm}$ in diameter), shape and free from visual damage or defects, washed initially with tap water, and allowed to dry for 1hour at room temperature.

Arabic gum powder was supplied by Jumbo Trading Co., Ltd. Bangkok, Thailand. To prepare gum arabic coating solutions at 5 and $10 \%$ $(W / V): 5$ and $10 \mathrm{~g}$ of powder was dissolved in $100 \mathrm{ml}$ purified water. The solutions were stirred with low heat $\left(40^{\circ} \mathrm{C}\right)$ for $60 \mathrm{~min}$ on a magnetic stirrer/hot plate (Model: HTS-1003), then filtered to remove any undissolved impurities using a vacuum flask. After cooling to $20^{\circ} \mathrm{C}$, glycerol monostearate $(1.0 \%)$ (Sigma) was added as a plasticiser to improve the 
strength and flexibility of the coating solutions. The $\mathrm{pH}$ of the solutions was maintained at 5.6 using $1 \mathrm{~N} \mathrm{NaOH}$.

The concentration of arabic gum, cellulose, pectin and xanthan were prepared by dissolving the required amounts in $1000 \mathrm{ml}$ distilled water. Cellulose, pectin and xanthan were obtained from El-Gomhoria Chemical Co., Egypt. While, arabic gum was purchased from perfumer.

Cherry tomato fruits were divided into 9 treatments as follows:

1. Fruits dipped in distilled water (control).

2. Fruits dipped in arabic gum solution at 5\%.

3. Fruits dipped in arabic gum solution at $10 \%$.

4. Fruits dipped in cellulose solution at $1 \%$.

5. Fruits dipped in cellulose solution at $2 \%$.

6. Fruits dipped in pectin solution at $1 \%$.

7. Fruits dipped in pectin solution at $2 \%$.

8. Fruits dipped in xanthan solution at $0.5 \%$.

9. Fruits dipped in xanthan solution at $1 \%$.

Each dipping treatment period was 5 minutes. All treatments of cherry tomato fruits were dried for $2 \mathrm{hr}$., at room temperature and packed in punntes, each punnet contained about $250 \mathrm{~g}$ represented as an experimental unit (EU) represted one replicate. Twelve (EU) from each treatment were prepared then placed in carton box and stored at $13^{\circ} \mathrm{C}$ and $90-95 \% \mathrm{RH}$. Samples were arranged in complete randomized design.

Three replicates (EU) were randomly taken and examined immediately after treatment and at 10 days intervals $(0,10,20,30$ and 40 days) for the following properties:

\section{Weight Loss Percentage}

Weight loss percentage of cherry tomatoes fruits were estimated according to the following equation:

Weight loss $(\%)=$ Initial fruit weight - fruit weight of sampling date $\div$ Initial fruit weight $\times 100$

\section{General Appearance}

General appearance was determined using score system of $9=$ excellent, $7=\operatorname{good}, 5=$ fair,
$3=$ poor, and $1=$ unsalable. This scale depends on the morphological defects such as shriveling or decay.

\section{Fruit Firmness}

Fruit firmness of each individual cherry tomato fruits was measured at two points of the equatorial region by Push Pull dynamometer (Model FD101). The firmness of the flesh was expressed as $\mathrm{g} / \mathrm{cm}^{2}$.

\section{Total Soluble Solids (TSS)}

The percentage of total soluble solids (TSS as brix $^{0}$ ) was determined by measuring the refractive index of fruit juice by a hand refractometer and the results were expressed as a percentage.

\section{Titratable Acidity (TA)}

The TA was measured by titration of 10 grams of fruit juice in $20 \mathrm{ml}$ distilled water with a solution of $0.1 \mathrm{~N} \mathrm{NaOH}$ using phenolphthalein as indicator. The titratable acidity $\mathrm{mg} / 100 \mathrm{ml}$ juice was expressed as citric acid according to the AOAC (2000).

\section{Lycopene Fruit Content}

It was determined by using petroleum ether method (Ranganna, 1979).

\section{pH}

$\mathrm{pH}$ of fruits juice was measured using a $\mathrm{pH}$ meter (HI 198/30 Hanna instrument).

\section{Ascorbic Acid Content (Vitamin C mg/ $100 \mathrm{ml}$ juice)}

It was determined using the dye 2, 6dichloro-phenol indophenols method (AOAC, 2000).

\section{Dry Matter (\%)}

It was determined after drying at $85^{\circ} \mathrm{C}$ till constant weight.

\section{Sensory Evaluation}

Sensory evaluation of the fruit for pulp colour, texture, flavour and overall acceptability for all the samples was done at the end of the storage period using the method of Bai $\boldsymbol{e t}$ al. (2003) with some modifications. Based on their consistency and reliability of judgment, a panel 
of seven judges with age ranging from 25 to 40 years was set up. Panelists were asked to score the difference between samples where 0-2 represented extreme dislike; 3-5 fair; 6-8 good; and 9 excellent for pulp colour, texture, flavour and overall acceptability

\section{Fungi and Culture}

Botrytis cinerea and Alternaria alternata, were obtained from Postharvest Diseases Department, Plant Pathology Research Institute, Agriculture Research Center (ARC) Giza, Egypt. All fungi were cultured on potato dextrose agar medium (PDA) packed in polypropylene bags and incubated overnight at $20 \pm 1^{\circ} \mathrm{C}$ under $85-90 \% \mathrm{RH}$.

\section{Effect of Edible Coating Treatments on Linear Growth of Botrytis cinerea and Alternaria alternata In vitro}

Arabic gum, cellulose, pectin and xanthan were evaluated for their capability to suppress fungal growth of Botrytis cinerea and Alternaria alternata in vitro. Each tested treatment was amended in PDA medium at concentrations of 5 and $10 \%$ for arabic gum, $1 \%$ and $2 \%$ for cellulose and pectin and 0.5 and $1 \%$ for xanthan treatments and they were added from stock solutions just before media pouring. The stock solutions were prepared using sterilized water and triton $\mathrm{B}$ as dispersal agent at the rate of $0.05 \%$. Treated and not-treated media with arabic gum, cellulose, pectin and xanthan were poured into Petri dishes 3 per each treatment. The control plates contained triton $\mathrm{B}$ at the concentration to the different added stock solution of arabic gum, cellulose, pectin and xanthan treatments. After medium solidification, Petri dishes were inoculated with inoculums discs of 7day-old culture of Botrytis cinerea and Alternaria alternata. Growth inhibition was calculated as the percentage of inhibition of the radial growth relative to the control. Mean diameters of linear growth were recorded and incubated at $20 \pm 1^{\circ} \mathrm{C}$ until the mycelium of any treatment cover the medium surface in the Petri dish. After incubation period, the linear growth $(\mathrm{mm})$ of each fungus was recorded and reduction percentages in colonies diameters caused by the tested treatments were calculated using the formula suggested by Fokemma (1973) as follows:

Reduction percentage $=\mathrm{de}-\mathrm{di} \div \mathrm{de} \times 100$
Where:

de $=$ maximum linear growth in control set .

$\mathrm{di}=$ maximum linear growth in treatment set.

Effect of Edible Coating Treatments on Decay Development in Artificially Inoculated Fruits

Fruits at turning stage of maturity were harvested, and transported to the laboratory one day before storage, and kept overnight at $13{ }^{\circ} \mathrm{C}$ and $90 \% \mathrm{RH}$. In the second day, uniform fruits, free of physical defects and fungal infections, were selected. Fruits were dipped in solution of $1 \%$ sodium hypochlorite for $2 \mathrm{~min}$, rinsed with tap water, and air dried before wounding. Cherry tomatoes were wounded with a sterile puncher to make uniform 2-mm deep $\times 5$-mm wide wound on their peel at the equatorial region. Aliquots of 5 and $10 \%$ for arabic gum, $1 \%$ and $2 \%$ of cellulose and pectin and 0.5 and $1 \%$ of xanthan, or sterile distilled water (control) were pipetted into each wounded site. After that, spore suspension of $B$. cinerea and A. alternata at a concentration of $4 \times 10^{6}$ spores $/ \mathrm{ml}$ were pipetted into each wound. Treated tomatoes were stored at $13^{\circ} \mathrm{C}$ and $90 \% \mathrm{RH}$ for 40 days. Severity of infection was estimated as percentage of the external rotten area in proportion to the total area of the fruit (Morcos, 1984). Decay percentage was expressed as number of rotten fruits per total fruits.

Efficiency $(\%)=$ Control disease severity Treatment disease severity $\div$ Control disease severity $\times 100$

\section{Statistical Analysis}

All data obtained were subjected to the proper statistical analysis using the MSTAT statistical software and the treatments means were compared by using the LSD at 0.05 level of probability as described by Snedecor and Cochran (1989).

\section{RESULTS AND DISCUSSION}

\section{Weight Loss Percentage}

It is clear from the results in Table 1 that there were a considerable and continuous increase in weight loss $(\%)$ as the storage period was extended from 0 to 40 days. Normally, the weight loss occurs during the fruit storage due to 
Table 1. Effect of some edible coating materials on weight loss percentage of cherry tomato fruits during cold storage in 2018 and 2019 seasons

\begin{tabular}{|c|c|c|c|c|c|c|c|c|c|c|c|c|}
\hline \multirow[t]{4}{*}{ Treatment (T) } & \multicolumn{12}{|c|}{ Weight loss (\%) } \\
\hline & \multicolumn{6}{|c|}{2018 season } & \multicolumn{6}{|c|}{2019 season } \\
\hline & \multicolumn{12}{|c|}{ Storage period in day $(\mathbf{S})$} \\
\hline & $\mathbf{0}$ & 10 & 20 & 30 & 40 & Mean & $\mathbf{0}$ & 10 & 20 & 30 & 40 & Mean \\
\hline$\overline{\text { Control }}$ & - & 1.56 & 2.09 & 3.11 & 5.58 & 3.08 & - & 1.51 & 2.03 & 3.05 & 5.53 & 3.03 \\
\hline Arabic gum at 5\% & - & 0.60 & 1.11 & 1.62 & 2.56 & 1.47 & - & 0.58 & 1.08 & 1.59 & 2.53 & 1.44 \\
\hline Arabic gum at $10 \%$ & - & 0.53 & 1.09 & 1.43 & 2.32 & 1.34 & - & 0.50 & 1.04 & 1.40 & 2.30 & 1.31 \\
\hline Cellulose at $1 \%$ & - & 0.80 & 1.40 & 2.35 & 4.26 & 2.20 & - & 0.79 & 1.36 & 2.32 & 4.22 & 2.17 \\
\hline Cellulose at $2 \%$ & - & 0.72 & 1.32 & 2.14 & 4.09 & 2.06 & - & 0.70 & 1.27 & 2.11 & 4.00 & 2.02 \\
\hline Pectin at $1 \%$ & - & 0.69 & 1.21 & 1.95 & 3.33 & 1.79 & - & 0.66 & 1.18 & 1.92 & 3.30 & 1.76 \\
\hline Pectin at $2 \%$ & - & 0.63 & 1.09 & 1.72 & 3.11 & 1.64 & - & 0.60 & 1.06 & 1.70 & 3.07 & 1.60 \\
\hline Xanthan at $0.5 \%$ & - & 1.35 & 1.82 & 2.85 & 4.58 & 2.65 & - & 1.30 & 1.77 & 2.80 & 4.52 & 2.60 \\
\hline Xanthan at $1 \%$ & - & 1.00 & 1.66 & 2.60 & 4.46 & 2.43 & - & 1.00 & 1.63 & 2.58 & 4.41 & 2.40 \\
\hline $\operatorname{Mean}(\mathbf{S})$ & - & 0.87 & 1.42 & 2.19 & 3.81 & - & - & 0.85 & 1.38 & 2.16 & 3.76 & - \\
\hline LSD at 0.05 level & \multicolumn{2}{|c|}{$\mathrm{T}=0.05$} & \multicolumn{2}{|c|}{$S=0.03$} & \multicolumn{2}{|c|}{$\mathrm{T} \times \mathrm{S}=0.09$} & \multicolumn{2}{|c|}{$\mathrm{T}=0.03$} & \multicolumn{2}{|c|}{$S=0.02$} & \multicolumn{2}{|c|}{$\mathrm{T} \times \mathrm{S}=0.05$} \\
\hline
\end{tabular}

Treatments $=(\mathrm{T})$, Storage period $=(\mathrm{S})$

its respiratory processes, the transference of humidity and some processes of oxidation (Sakaldas and Kaynas, 2010). In support to this result, Ibrahim and Abdullah (2018), on tomato and sweet pepper and Abdullah and Ibrahim (2018) on cherry tomato, found that increasing storage period significantly increase weight loss percentage of fruits.

With regard to treatments, results in Table 1 show that weight loss percentage of tomato fruits was significant by different tested materials as compared with control treatment during storage period. Cherry tomato fruits which coated with arabic gum at $10 \%$ or $5 \%$ were the most effective treatments with significant difference between them, followed by pectin at $2 \%$ or $1 \%$ with significant difference between them, while the other treatments were less effect in this concern. The highest value of weight loss percentage was observed in case of control treatment. This reduction in weight loss was probably due to the effect of the coating as a semi-permeable barrier against $\mathrm{O}_{2}, \mathrm{CO}_{2}$, moisture and solute movement, which decreased respiration rate, water loss and oxidation reaction rates and consequently retarded fresh weight loss (Baldwin et al., 1999).

These results are similar to those found by Ali et al. (2010) and Ruelas-Chacon et al. (2017) for arabic gum on tomato and Abebe $\boldsymbol{e t}$ al. (2017) for pectin.

With respect to the interaction between treatments and storage period on the loss in weight the same results in Table 1 show significant effect in both seasons, the minimum weight loss (\%) at the end of storage period (40 days) was noticed by the fruits which dipped in arabic gum at $10 \%$ that gave 2.32 and $2.30 \%$ in the first and second seasons, respectively, followed by arabic gum at 5\% which recorded 2.56 and $2.53 \%$ in both seasons, respectively. On the contrary, the maximum value of weight loss percentage at the end of storage period (40 days) was recorded by control treatment which gave 5.58 and $5.53 \%$ in first and second seasons, respectively. 


\section{General Appearance (GA)}

Results in Table 2 show that, general appearance (score) of cherry tomato fruits declined with the prolonging of storage period in both seasons, where the minimum values were occurred at the end of storage period. The decrease of general appearance during storage period might be due to shriveling, colour change and decay (Gonzalez-Aguilar et al., 1997). Similar results were obtained by Abdullah and Ibrahim (2018) on cherry tomato and Ibrahim and Abdullah (2018), on tomato and sweet pepper. With respect to treatments, results in Table 2 show that, cherry tomato fruits coated with arabic gum at $5 \%$ or $10 \%$ gave the beast appearance (higher score) with no significant differences between them in the two seasons followed by cellulose treatment at $2 \%$ and pectin at 1 or $2 \%$ with no significant differences between them in the two seasons, while the other treatments and untreated (control) gave the lowest score of general appearance. The keeping quality of general appearance was improved by using arabic gum attributed to the effect of arabic gum on the reduction of weight loss and rot rate of cherry tomato fruits. Arabic gum treatments have beneficial effects on fruit physiology such as delaying ripening of fruits, in the same time ethylene production by fruits can be reduced by arabic gum (Ali et al., 2013), and this reduction keeps the appearance of fruits in the beat state. Regarding the effect of interaction between edible coating materials and storage period, results in Table 2 show significant effect on general appearance, the minimum values of $\mathrm{AG}$ at the end of storage period (40 days) were noticed by the fruits which coated with xanthan at 0.5 and $1 \%$ and control without significant differences among them, they gave 5.67 in both seasons. On the contrary, the maximum values of AG at the end of storage period were recorded by tomato fruits which coated with arabic gum at 5 or $10 \%$ and cellulose at $2 \%$ which displayed acceptable appearance without any pathological signs in both seasons of study.

\section{Fruit Firmness}

It is obvious from the results in Table 3 that firmness of cherry tomato decreased as the duration of storage period increased, the highest values of fruit firmness were recorded at harvesting time $\left(640\right.$ and $\left.660 \mathrm{~g} / \mathrm{cm}^{2}\right)$ in the first and second seasons, respectively while the lowest values were noticed at the end of storage period, these results are true in both seasons.

The post harvest storage of fruit is accompanied by loss of cell wall integrity due to breakdown of peptic substances, which led to an increase in soluble pectin and decrease in fruit firmness (Mirdehghan et al., 2007). Similar results were obtained by Abdullah and Ibrahim (2018) on cherry tomato and Ibrahim and Abdullah (2018) on tomato and sweet pepper.

Regarding treatments, it is clear from the results in Table 3 that coating cherry tomato fruits with the most of tested substances had significant effect on fruit firmness. Cherry tomato fruits which coated with arabic gum at $10 \%$ or $5 \%$ and pectin at $2 \%$ were the most effective treatments in reducing the loss of firmness without significant difference among them, while the other treatments were less effect in this concern. On the other hand the lowest values of fruit firmness were recorded by control treatment, these results are true in both seasons of study.

Concerning the effect of interaction between edible coating materials and storage period, the same results showed significant effects in both seasons, the maximum values of fruit firmness at the end of storage period (40days) were noticed by the fruits which coated with arabic gum at $10 \%$ that gave 570 and $610 \mathrm{~g} / \mathrm{cm}^{2}$ in the $1^{\text {st }}$ and $2^{\text {nd }}$ seasons, respectively followed by arabic gum at $5 \%$.

\section{Total Soluble Solids (TSS)}

It is obvious from the results in Table 4 that a pronounced increase was recorded in TSS percentage of cherry tomato fruits until the end of storage period (40 days). The lowest values of TSS were recorded at the beginning of storage, where the highest values were recorded at the end of storage period in both seasons. The increase in TSS(\%) at the end of storage might owe much to the higher rate of moisture loss through respiration.

As for the effect of treatments, it is clear from the results in Table 4 that coating cherry tomato fruits with the most of tested substances had significant effect on total soluble solids. The lowest values in this respect were recorded by arabic gum at $10 \%$ followed by arabic gum at 
Table 2. Effect of some edible coating materials on general appearance of cherry tomato fruits during cold storage during 2018 and 2019 seasons

\begin{tabular}{|c|c|c|c|c|c|c|c|c|c|c|c|c|}
\hline \multirow[t]{4}{*}{ Treatment (T) } & \multicolumn{12}{|c|}{ General appearance score* } \\
\hline & \multicolumn{6}{|c|}{2018 season } & \multicolumn{6}{|c|}{2019 season } \\
\hline & \multicolumn{12}{|c|}{ Storage period in day (S) } \\
\hline & $\mathbf{0}$ & 10 & 20 & 30 & 40 & Mean & $\mathbf{0}$ & 10 & 20 & 30 & 40 & Mean \\
\hline$\overline{\text { Control }}$ & 9.00 & 9.00 & 9.00 & 6.67 & 5.67 & 8.07 & 9.00 & 9.00 & 9.00 & 8.00 & 5.67 & 8.13 \\
\hline Arabic gum at 5\% & 9.00 & 9.00 & 9.00 & 9.00 & 7.67 & 8.73 & 9.00 & 9.00 & 9.00 & 9.00 & 7.67 & 8.73 \\
\hline Arabic gum at $10 \%$ & 9.00 & 9.00 & 9.00 & 9.00 & 7.67 & 8.73 & 9.00 & 9.00 & 9.00 & 9.00 & 7.67 & 8.73 \\
\hline Cellulose at $1 \%$ & 9.00 & 9.00 & 9.00 & 8.33 & 5.67 & 8.20 & 9.00 & 9.00 & 9.00 & 8.33 & 5.67 & 8.20 \\
\hline Cellulose at $2 \%$ & 9.00 & 9.00 & 9.00 & 8.67 & 7.67 & 8.67 & 9.00 & 9.00 & 9.00 & 8.67 & 6.67 & 8.47 \\
\hline Pectin at $1 \%$ & 9.00 & 9.00 & 9.00 & 9.00 & 6.67 & 8.53 & 9.00 & 9.00 & 9.00 & 9.00 & 6.67 & 8.53 \\
\hline Pectin at $2 \%$ & 9.00 & 9.00 & 9.00 & 9.00 & 6.67 & 8.53 & 9.00 & 9.00 & 9.00 & 9.00 & 6.67 & 8.53 \\
\hline Xanthan at $0.5 \%$ & 9.00 & 9.00 & 9.00 & 8.33 & 5.67 & 8.20 & 9.00 & 9.00 & 9.00 & 8.33 & 5.67 & 8.20 \\
\hline Xanthan at $1 \%$ & 9.00 & 9.00 & 9.00 & 8.33 & 5.67 & 8.20 & 9.00 & 9.00 & 9.00 & 8.33 & 5.67 & 8.20 \\
\hline Mean (S) & 9.00 & 9.00 & 9.00 & 8.59 & 6.54 & - & 9.00 & 9.00 & 9.00 & 8.63 & 6.44 & - \\
\hline LSD at 0.05 level & $\mathrm{T}=$ & 0.26 & $S=0$ & & $\mathrm{~T} \times \mathrm{S}=$ & 0.47 & $\mathrm{~T}=0$ & & $S=0$. & .18 & $\mathrm{~T} \times \mathrm{S}=$ & 0.53 \\
\hline
\end{tabular}

* Score: 9= Excellent, 7= Good, 5= Fair, 3= Poor Treatments $=(T)$, Storage period $=(\mathrm{S})$

Table 3. Effect of some edible coating materials on fruit firmness of cherry tomato during cold storage during 2018 and 2019 seasons

\begin{tabular}{|c|c|c|c|c|c|c|c|c|c|c|c|c|}
\hline \multirow[t]{4}{*}{ Treatment (T) } & \multicolumn{12}{|c|}{ Fruit firmness $\left(\mathrm{g} / \mathrm{cm}^{2}\right)$} \\
\hline & \multicolumn{6}{|c|}{2018 season } & \multicolumn{6}{|c|}{2019 season } \\
\hline & \multicolumn{12}{|c|}{ Storage period in day $(S)$} \\
\hline & $\mathbf{0}$ & 10 & 20 & 30 & 40 & Mean & $\mathbf{0}$ & $\mathbf{1 0}$ & 20 & 30 & 40 & Mean \\
\hline$\overline{\text { Control }}$ & 640 & 620 & 600 & 560 & 480 & 580 & 660 & 640 & 620 & 570 & 500 & 598 \\
\hline Arabic gum at $5 \%$ & 640 & 630 & 620 & 600 & 560 & 610 & 660 & 650 & 640 & 620 & 590 & 632 \\
\hline Arabic gum at $10 \%$ & 640 & 630 & 620 & 600 & 570 & 612 & 660 & 650 & 640 & 630 & 610 & 638 \\
\hline Cellulose at $1 \%$ & 640 & 610 & 600 & 580 & 520 & 590 & 660 & 640 & 630 & 590 & 540 & 612 \\
\hline Cellulose at $2 \%$ & 640 & 610 & 600 & 580 & 540 & 594 & 660 & 640 & 640 & 600 & 550 & 618 \\
\hline Pectin at $1 \%$ & 640 & 630 & 620 & 600 & 550 & 608 & 660 & 650 & 640 & 620 & 560 & 626 \\
\hline Pectin at $2 \%$ & 640 & 630 & 620 & 600 & 560 & 610 & 660 & 650 & 640 & 630 & 570 & 630 \\
\hline Xanthan at $0.5 \%$ & 640 & 620 & 610 & 570 & 510 & 590 & 660 & 640 & 630 & 580 & 540 & 610 \\
\hline Xanthan at $1 \%$ & 640 & 620 & 600 & 560 & 500 & 584 & 660 & 640 & 620 & 570 & 520 & 602 \\
\hline Mean (S) & 640 & 622 & 610 & 583 & 532 & - & 660 & 644 & 633 & 601 & 553 & - \\
\hline LSD at 0.05 level & & $=9$ & $S=$ & & $\mathrm{T} \times \mathrm{S}$ & & & 13 & & $=3$ & $\mathrm{~T} \times \mathrm{S}$ & \\
\hline
\end{tabular}

Treatments $=(\mathrm{T})$, Storage period $=(\mathrm{S})$ 
Table 4. Effect of some edible coating materials on total soluble solids of cherry tomato fruits during cold storage in 2018 and 2019 seasons

\begin{tabular}{|c|c|c|c|c|c|c|c|c|c|c|c|c|}
\hline \multirow[t]{4}{*}{ Treatment $(\mathbf{T})$} & \multicolumn{12}{|c|}{ TSS $\left(\right.$ Brix $\left.^{\circ}\right)$} \\
\hline & \multicolumn{6}{|c|}{2018 season } & \multicolumn{6}{|c|}{2019 season } \\
\hline & \multicolumn{12}{|c|}{ Storage period in day (S) } \\
\hline & $\mathbf{0}$ & 10 & 20 & 30 & 40 & Mean & $\mathbf{0}$ & 10 & 20 & 30 & 40 & Mean \\
\hline Control & 7.50 & 8.33 & 8.50 & 9.17 & 9.50 & 8.60 & 7.17 & 8.50 & 9.17 & 9.50 & 10.0 & 8.87 \\
\hline Arabic gum at $5 \%$ & 7.50 & 7.67 & 8.17 & 8.33 & 8.50 & 8.03 & 7.17 & 7.50 & 7.67 & 8.00 & 8.17 & 7.70 \\
\hline Arabic gum at $10 \%$ & 7.50 & 7.67 & 8.00 & 8.17 & 8.33 & 7.93 & 7.17 & 7.33 & 7.50 & 7.67 & 8.00 & 7.53 \\
\hline Cellulose at $1 \%$ & 7.50 & 8.00 & 8.50 & 8.67 & 9.17 & 8.37 & 7.17 & 8.00 & 8.50 & 9.00 & 9.33 & 8.40 \\
\hline Cellulose at $2 \%$ & 7.50 & 8.00 & 8.17 & 8.50 & 8.67 & 8.17 & 7.17 & 8.00 & 8.33 & 8.67 & 9.17 & 8.27 \\
\hline Pectin at $1 \%$ & 7.50 & 8.00 & 8.50 & 8.67 & 9.00 & 8.33 & 7.17 & 7.67 & 8.17 & 8.50 & 9.00 & 8.10 \\
\hline Pectin at $2 \%$ & 7.50 & 7.67 & 8.17 & 8.33 & 8.50 & 8.03 & 7.17 & 7.67 & 8.00 & 8.17 & 8.33 & 7.87 \\
\hline Xanthan at $0.5 \%$ & 7.50 & 8.17 & 8.33 & 9.50 & 9.67 & 8.63 & 7.17 & 8.17 & 8.67 & 9.17 & 9.50 & 8.53 \\
\hline Xanthan at $1 \%$ & 7.50 & 8.17 & 8.67 & 9.67 & 10.0 & 8.80 & 7.17 & 8.50 & 9.00 & 9.33 & 9.67 & 8.73 \\
\hline Mean (S) & 7.50 & 7.96 & 8.33 & 8.78 & 9.04 & - & 7.17 & 7.92 & 8.33 & 8.67 & 9.02 & - \\
\hline LSD at 0.05 level & & 0.22 & $S=0$ & $30 \mathrm{~T}$ & $S=($ & & $\mathrm{T}=$ & 28 & $S=0$ & & $\mathrm{~T} \times S$ & $=0.73$ \\
\hline
\end{tabular}

Treatments $=(\mathrm{T})$, Storage period $=(\mathrm{S})$

$5 \%$ and pectin at $2 \%$. On the other hand the highest values of total soluble solids were recorded by control treatment and xanthan at $1 \%$, these results are true in both seasons of study.

Regarding the effect of interaction between edible coating materials and storage periods, the same results showed significant effect in both seasons, the minimum values of total soluble solids at the end of storage period (40 days) were noticed by the fruits which coated with arabic gum at $10 \%$ that gave 8.33 and $8.00^{\circ}$ Brix in the $1^{\text {st }}$ and $2^{\text {nd }}$ seasons, respectively followed by arabic gum at $5 \%$.

\section{Titratable Acidity}

It is clear from the results in Table 5 that there were a considerable and continuous decrease in titratable acidity as the storage period was extended from 0 to 40 days, the minimum values of titratable acidity were occurred at the end of storage period and it reached to 2.24 and $2.26(\mathrm{mg} / 100 \mathrm{ml}$ juice $)$ in the first and second seasons, respectively. Similar results were obtained by Abdullah and Ibrahim (2018) on cherry tomato.
Respecting treatments, it is clear from the results in Table 5 that coating cherry tomato fruits with all tested substances had significant effect on titratable acidity. Cherry tomato fruits which coated with arabic gum at $10 \%$ or $5 \%$ were the most effective treatments in reducing the loss of titratable acidity without significant difference between them, while the other treatments were less effect in this concern. On the other hand the lowest values of titratable acidity were recorded in case of control treatment, these results are true in both seasons of study.

As for the effect of interaction between edible coating materials and storage period, results in Table 5 showed significant effect in both seasons, the maximum values of titratable acidity at the end of storage period (40 days) were noticed by the fruits which coated with arabic gum at $10 \%$ that gave 2.64 and 2.86 $(\mathrm{mg} / 100 \mathrm{ml}$ juice $)$ in the $1^{\text {st }}$ and $2^{\text {nd }}$ seasons, respectively followed by arabic gum at $5 \%$. On the other hand the lowest values in this respect were recorded in case of control treatment. 
Table 5. Effect of some edible coating materials on titratable acidity of cherry tomato fruits during cold storage in 2018 and 2019 seasons

\begin{tabular}{|c|c|c|c|c|c|c|c|c|c|c|c|}
\hline \multirow[t]{4}{*}{ Treatment (T) } & \multicolumn{11}{|c|}{ Titratable acidity (mg/100ml juice) } \\
\hline & \multicolumn{6}{|c|}{2018 season } & \multicolumn{5}{|c|}{2019 season } \\
\hline & \multicolumn{11}{|c|}{ Storage period in day (S) } \\
\hline & $\mathbf{0}$ & 10 & 20 & 30 & 40 & Mean & $\mathbf{0}$ & 10 & 30 & 40 & Mean \\
\hline Control & 3.50 & 2.86 & 2.43 & 2.19 & 1.80 & 2.55 & 3.65 & 2.73 & 2.252 .20 & 1.82 & 2.53 \\
\hline Arabic gum at 5\% & 3.50 & 3.41 & 3.18 & 2.88 & 2.60 & 3.11 & 3.65 & 3.40 & 3.173 .00 & 2.73 & 3.19 \\
\hline Arabic gum at $10 \%$ & 3.50 & 3.46 & 3.22 & 3.00 & 2.64 & 3.16 & 3.65 & 3.44 & 3.213 .11 & 2.86 & 3.25 \\
\hline Cellulose at $1 \%$ & 3.50 & 3.25 & 2.84 & 2.50 & 2.10 & 2.84 & 3.65 & 3.20 & 2.552 .54 & 2.30 & 2.85 \\
\hline Cellulose at $2 \%$ & 3.50 & 3.30 & 2.91 & 2.66 & 2.22 & 2.92 & 3.65 & 3.23 & 2.602 .61 & 2.36 & 2.89 \\
\hline Pectin at $1 \%$ & 3.50 & 3.33 & 3.00 & 2.71 & 2.30 & 2.97 & 3.65 & 3.30 & 2.872 .80 & 2.18 & 2.96 \\
\hline Pectin at $2 \%$ & 3.50 & 3.38 & 3.16 & 2.85 & 2.55 & 3.09 & 3.65 & 3.38 & 3.002 .88 & 2.24 & 3.03 \\
\hline Xanthan at $0.5 \%$ & 3.50 & 3.20 & 2.76 & 2.40 & 2.00 & 2.77 & 3.65 & 3.10 & 2.392 .33 & 2.00 & 2.69 \\
\hline Xanthan at $1 \%$ & 3.50 & 3.00 & 2.64 & 2.32 & 1.93 & 2.68 & 3.65 & 3.06 & 2.362 .30 & 1.90 & 2.65 \\
\hline Mean (S) & 3.50 & 3.24 & 2.90 & 2.61 & 2.24 & - & 3.65 & 3.20 & 2.712 .64 & 2.26 & - \\
\hline LSD at 0.05 level & $\mathrm{T}=$ & 0.06 & $\mathrm{~S}=0$ & & $\mathrm{~T} \times \mathrm{S}=$ & 0.14 & $\mathrm{~T}=\mathrm{C}$ & & $S=0.04$ & $\mathrm{~T} \times \mathrm{S}=$ & $=0.11$ \\
\hline
\end{tabular}

Treatments $=(\mathrm{T})$, Storage period $=(\mathrm{S})$

\section{Lycopene Content}

Results in Table 6 show that lycopene content was gradually increased as the storage time increased, where the minimum values were occurred at the beginning of storage, and then increased significantly with the prolongation of the storage period in the two seasons, meanwhile the maximum values were noticed at the end of storage period (76.1 and $73.5 \mathrm{mg} / 100$ g F.W) in the first and second seasons, respectively. The increasing in lycopene content with the elapse of storage period may be due to that, production of lycopene content is directly correlated with ripening, and the formation of lycopene depends on the temperature range and rate of respiration during storage (Javanmardi and Kubota, 2006). These results are in agreement with those obtained by Ali $\boldsymbol{e t}$ al. (2013) on tomato and Abdullah and Ibrahim (2018) on cherry tomato.

Concerning treatments, it is obvious from the same data in Table 6 that, treating cherry tomato fruits with all tested materials significantly decreased lycopene content of tomato fruits as compared to control treatment which significantly increased lycopene content in both seasons of study. The superior treatments for decreasing lycopene content, arabic gum at $10 \%$ or $5 \%$ which were the most effective treatments with significant difference between them. The early increase in lycopene content in untreated fruits might be due to the faster ripening of fruits than in the fruits treated with other material, while, arabic gum treatments have beneficial effects on fruit physiology such as delaying ripening of fruits, in the same time slowed down the respiration rate and ethylene production in tomato (Ali et al., 2013).

As for the effect of interaction between edible coating materials and storage period, results in Table 6 show significant effect on lycopene content in both seasons of study, the minimum values at the end of storage period (40 days) were noticed by tomato fruits which coated with arabic gum at $10 \%$ that recorded 65.8 and $62.5 \mathrm{mg} / 100 \mathrm{gm} \mathrm{F.W} \mathrm{followed} \mathrm{by}$ arabic gum at 5\% which gave 67.7 and 65.2 in the first and second seasons, respectively. Similar results were obtained by Ali $\boldsymbol{e t} \boldsymbol{a l}$. (2013) on tomato. 
Table 6. Effect of some edible coating materials on lycopene pigment of cherry tomato fruits during cold storage in 2018 and 2019 seasons

\begin{tabular}{|c|c|c|c|c|c|c|c|c|c|c|c|}
\hline \multirow[t]{4}{*}{ Treatment (T) } & \multicolumn{11}{|c|}{ Lycopene (mg/100gm F.W) } \\
\hline & \multicolumn{6}{|c|}{2018 season } & \multicolumn{5}{|c|}{2019 season } \\
\hline & \multicolumn{11}{|c|}{ Storage period in day $(\mathrm{S})$} \\
\hline & $\mathbf{0}$ & 10 & 20 & 30 & 40 & Mean & $\mathbf{0}$ & 10 & 20 & 40 & Mean \\
\hline$\overline{\text { Control }}$ & 35.5 & 60.4 & 65.3 & 83.4 & 89.0 & 66.7 & 28.2 & 50.2 & 55.370 .2 & 84.5 & 57.7 \\
\hline Arabic gum at $5 \%$ & 35.5 & 41.6 & 49.0 & 54.1 & 67.7 & 49.6 & 28.2 & 38.5 & 42.653 .7 & 65.2 & 45.6 \\
\hline Arabic gum at $10 \%$ & 35.5 & 39.7 & 43.2 & 52.7 & 65.8 & 47.4 & 28.2 & 35.3 & 40.251 .8 & 62.5 & 43.6 \\
\hline Cellulose at $1 \%$ & 35.5 & 49.3 & 59.1 & 69.4 & 79.7 & 58.6 & 28.2 & 44.6 & 49.363 .4 & 75.8 & 52.3 \\
\hline Cellulose at $2 \%$ & 35.5 & 47.2 & 57.8 & 66.2 & 76.4 & 56.6 & 28.2 & 42.3 & 47.461 .2 & 72.4 & 50.3 \\
\hline Pectin at $1 \%$ & 35.5 & 45.5 & 55.6 & 63.4 & 71.2 & 54.2 & 28.2 & 40.8 & 46.658 .9 & 69.5 & 48.8 \\
\hline Pectin at $2 \%$ & 35.5 & 43.8 & 52.5 & 60.2 & 69.8 & 52.3 & 28.2 & 39.6 & 44.256 .1 & 67.7 & 47.1 \\
\hline Xanthan at $0.5 \%$ & 35.5 & 59.6 & 63.4 & 80.6 & 85.4 & 64.9 & 28.2 & 49.3 & 53.769 .2 & 83.4 & 56.7 \\
\hline Xanthan at $1 \%$ & 35.5 & 53.0 & 59.2 & 76.1 & 80.1 & 60.8 & 28.2 & 47.0 & 50.066 .5 & 80.3 & 54.4 \\
\hline $\operatorname{Mean}(\mathbf{S})$ & 35.5 & 48.9 & 56.1 & 67.3 & 76.1 & - & 28.2 & 43.1 & 47.761 .3 & 73.5 & - \\
\hline LSD at 0.05 level & & $=1.1$ & $S=0$ & & $\mathrm{~T} \times \mathrm{S}=$ & & & 0.5 & $S=0.4$ & $\mathrm{~T} \times \mathrm{S}=$ & 1.2 \\
\hline
\end{tabular}

Treatments $=(\mathrm{T})$, Storage period $=(\mathrm{S})$

\section{pH}

It is clear from the results in Table 7 that there were a considerable and continuous decrease in $\mathrm{pH}$ values as the storage period was extended from 0 to 40 days, the minimum values of $\mathrm{pH}$ values were occurred at the end of storage period and it reached to 2.64 and 2.78 in the first and second seasons, respectively. Similar results were obtained by Raafat $\boldsymbol{e t}$ al. (2016) on cherry tomato.

Regarding treatments, it is clear from results in Table 7 that coating cherry tomato fruits with all tested materials had significant effect on $\mathrm{pH}$ values. Cherry tomato fruits which coated with arabic gum at $10 \%$ or $5 \%$ were the most effective treatments without significant difference between them followed by pectin at $2 \%$, while the other treatments were less effect in this concern. On the other hand the lowest values of $\mathrm{pH}$ were recorded in case of control treatment, these results are true in both seasons of study with respect to the effect of interaction between edible coating materials and storage period, the same results showed (Table 7) significant effect in both seasons, the maximum values of $\mathrm{pH}$ at the end of storage period (40 days) were noticed by the fruits which coated with arabic gum at $10 \%$ that gave 3.00 and 3.23 in the $1^{\text {st }}$ and $2^{\text {nd }}$ seasons, respectively, followed by arabic gum at $5 \%$. On the other hand the lowest values in this respect were recorded in case of control treatment.

\section{Vitamin C}

Results presented in Table 8 indicate that there were a significant reduction in vitamin $\mathrm{C}$ content with the increase of storage period from 0 to 40 days, the minimum values of vitamin $\mathrm{C}$ content were occurred at the end of storage period and it reached to 15.48 and 15.91 $\mathrm{mg} / 100 \mathrm{ml}$ juice in the first and second seasons, respectively. Wills et al. (1981) attributed the reduction of Vitam. C during storage to great metabolic activity during storage as it is respired. Paradis et al. (1995) found that the reduction in ascorbic acid content during storage period might have been due to the higher rate of 
Table 7. Effect of some edible coating materials on $\mathrm{pH}$ values of cherry tomato fruits during cold storage in 2018 and 2019 seasons

\begin{tabular}{|c|c|c|c|c|c|c|c|c|c|c|c|c|}
\hline \multirow[t]{4}{*}{$\overline{\text { Treatment }(\mathrm{T})}$} & \multicolumn{12}{|c|}{ pH values } \\
\hline & \multicolumn{6}{|c|}{2018 season } & \multicolumn{6}{|c|}{2019 season } \\
\hline & \multicolumn{12}{|c|}{ Storage period in day $(\mathrm{S})$} \\
\hline & $\overline{\mathbf{0}}$ & 10 & 20 & 30 & 40 & Mean & $\mathbf{0}$ & 10 & 20 & 30 & 40 & Mean \\
\hline Control & 4.25 & 3.42 & 3.22 & 2.81 & 2.22 & 3.18 & 4.50 & 3.66 & 3.34 & 2.94 & 2.34 & 3.35 \\
\hline Arabic gum at 5\% & 4.25 & 3.92 & 3.70 & 3.52 & 2.94 & 3.66 & 4.50 & 4.20 & 3.75 & 3.60 & 3.20 & 3.85 \\
\hline Arabic gum at $10 \%$ & 4.25 & 4.00 & 3.81 & 3.60 & 3.00 & 3.73 & 4.50 & 4.23 & 3.83 & 3.66 & 3.23 & 3.89 \\
\hline Cellulose at $1 \%$ & 4.25 & 3.65 & 3.48 & 3.20 & 2.60 & 3.44 & 4.50 & 3.70 & 3.52 & 3.29 & 2.66 & 3.53 \\
\hline Cellulose at $2 \%$ & 4.25 & 3.71 & 3.53 & 3.27 & 2.65 & 3.48 & 4.50 & 3.82 & 3.60 & 3.32 & 2.70 & 3.59 \\
\hline Pectin at $1 \%$ & 4.25 & 3.80 & 3.60 & 3.38 & 2.71 & 3.55 & 4.50 & 3.91 & 3.70 & 3.40 & 2.85 & 3.67 \\
\hline Pectin at $2 \%$ & 4.25 & 3.84 & 3.64 & 3.43 & 2.83 & 3.60 & 4.50 & 4.00 & 3.72 & 3.48 & 3.07 & 3.75 \\
\hline Xanthan at $0.5 \%$ & 4.25 & 3.55 & 3.35 & 3.11 & 2.44 & 3.34 & 4.50 & 3.86 & 3.52 & 3.16 & 2.52 & 3.51 \\
\hline Xanthan at $1 \%$ & 4.25 & 3.50 & 3.30 & 3.00 & 2.38 & 3.28 & 4.50 & 3.75 & 3.43 & 3.00 & 2.46 & 3.43 \\
\hline Mean (S) & 4.25 & 3.71 & 3.51 & 3.26 & 2.64 & - & 4.50 & 3.90 & 3.60 & 3.32 & 2.78 & - \\
\hline LSD at 0.05 level & $\mathrm{T}=$ & 0.09 & $\mathrm{~S}=0$ & & $\mathrm{~T} \times \mathrm{S}=$ & .19 & $\mathrm{~T}=\mathrm{C}$ & & $S=0$ & .05 & $\mathrm{~T} \times \mathrm{S}=$ & $=0.14$ \\
\hline
\end{tabular}

Treatments $=(\mathrm{T})$, Storage period $=(\mathrm{S})$

Table 8. Effect of some edible coating materials on vitamin $\mathrm{C}$ of cherry tomato fruits during cold storage in 2018 and 2019 seasons

\begin{tabular}{|c|c|c|c|c|c|c|c|c|c|c|c|}
\hline \multirow[t]{4}{*}{$\overline{\text { Treatment }(\mathrm{T})}$} & \multicolumn{11}{|c|}{ Vitamin C (mg/100ml juice) } \\
\hline & \multicolumn{6}{|c|}{2018 season } & \multicolumn{5}{|c|}{2019 season } \\
\hline & \multicolumn{11}{|c|}{ Storage period in day $(\mathrm{S})$} \\
\hline & $\mathbf{0}$ & 10 & 20 & 30 & 40 & Mean & $\mathbf{0}$ & 10 & 30 & 40 & Mean \\
\hline$\overline{\text { Control }}$ & 20.40 & 17.00 & 16.60 & 15.00 & 14.00 & 16.60 & 21.10 & 17.60 & 16.8015 .10 & 14.40 & 17.00 \\
\hline Arabic gum at 5\% & 20.40 & 19.60 & 19.10 & 17.00 & 16.80 & 18.58 & 21.10 & 19.80 & 19.3018 .00 & 17.00 & 19.04 \\
\hline Arabic gum at $10 \%$ & 620.40 & 19.80 & 19.20 & 17.50 & 17.10 & 18.80 & 21.10 & 20.20 & 19.7018 .20 & 17.40 & 19.32 \\
\hline Cellulose at $1 \%$ & 20.40 & 18.40 & 18.10 & 15.70 & 15.00 & 17.52 & 21.10 & 18.70 & 18.0016 .20 & 15.40 & 17.88 \\
\hline Cellulose at $2 \%$ & 20.40 & 18.60 & 18.20 & 16.00 & 15.40 & 17.72 & 21.10 & 19.00 & 18.6016 .50 & 16.00 & 18.24 \\
\hline Pectin at $1 \%$ & 20.40 & 19.00 & 18.40 & 16.10 & 15.70 & 17.92 & 21.10 & 19.40 & 18.2017 .10 & 16.50 & 18.46 \\
\hline Pectin at $2 \%$ & 20.40 & 19.30 & 18.80 & 16.40 & 16.00 & 18.18 & 21.10 & 19.60 & 19.0017 .60 & 16.80 & 18.82 \\
\hline Xanthan at $0.5 \%$ & 20.40 & 18.00 & 17.60 & 15.40 & 14.80 & 17.24 & 21.10 & 18.40 & 17.5015 .80 & 15.00 & 17.56 \\
\hline Xanthan at $1 \%$ & 20.40 & 17.50 & 17.00 & 15.10 & 14.50 & 16.90 & 21.10 & 18.00 & 17.1015 .30 & 14.70 & 17.24 \\
\hline $\operatorname{Mean}(\mathbf{S})$ & 20.40 & 18.58 & 18.11 & 16.02 & 15.48 & - & 21.10 & 18.96 & 18.2416 .64 & 15.91 & - \\
\hline LSD at 0.05 level & $\mathrm{T}=$ & $=0.45$ & $S=($ & .54 & $\mathrm{~T} \times \mathrm{S}$ & 1.64 & $\mathrm{~T}=$ & .52 & $S=0.43$ & $T \times$ & 1.28 \\
\hline
\end{tabular}


sugar loss through respiration than water loss through transpiration. These results agree with Raafat et al. (2016) and Abdullah and Ibrahim (2018) on cherry tomato, Ibrahim and Abdullah (2018), on tomato and sweet pepper.

With respect to treatments, it is clear from the results in Table 8 that coating cherry tomato fruits with the most of tested materials had significant effect on vitamin $\mathrm{C}$ content. The superior treatments in reducing the loss of vitamin $\mathrm{C}$ were arabic gum at $10 \%$ or $5 \%$ followed by pectin at $2 \%$ without significant difference among them, while the other treatments were less effective in this concern. On the other contrary the lowest values of vitamin $\mathrm{C}$ content were recorded in case of control treatment, these results are true in both seasons of study. Similar results were obtained by Ali et al. (2010) for arabic gum on tomato.

Regarding to the effect of interaction between edible coating materials and storage period, the same results showed significant effect in both seasons, the maximum values of vitamin $\mathrm{C}$ content at the end of storage period (40 days) were noticed by the fruits which coated with arabic gum at $10 \%$ that gave 17.10 and 17.40 $\mathrm{mg} / 100 \mathrm{ml}$ juice in the $1^{\text {st }}$ and $2^{\text {nd }}$ seasons respectively, followed by arabic gum at 5\% which recorded 16.80 and $17.00 \mathrm{mg} / 100 \mathrm{ml}$ juice in the first and second seasons, respectively, without significant differences between them. On the other side, the lowest values in this respect were recorded in case of control treatment.

\section{Dry Matter Percentage}

It is clear from the results in Table 9 that there were a significant reduction in dry matter percentage with the increase of storage period from 0 to 40 days, the minimum values of dry matter percentage were occurred at the end of storage period and it reached to 7.60 and $7.53 \%$ in the first and second seasons, respectively. The decline in dry matter percentage may be due to the higher rate of dry matter consumption through respiration than that of moisture loss through transpiration rate.

Regarding treatments, it is clear from the results in Table 9 that coating cherry tomato fruits with all tested materials had significant effect on dry matter percentage. Cherry tomato fruits which coated with arabic gum at $10 \%$ or
$5 \%$ were the most effective treatments, in maintaining dry matter (\%) during storage followed by pectin at $2 \%$ with significant difference among them, while the other treatments were less effective in this concern. On the other side the lowest values of dry matter percentage were recorded in case of control treatment, these results are true in both seasons of study with respect to the effect of interaction between edible coating materials and storage period. The same results showed significant effect in both seasons, the maximum values of dry matter $(\%)$ at the end of storage period (40 days) were noticed by the fruits which coated with arabic gum at $10 \%$ that gave 8.24 and $8.43 \%$ in the $1^{\text {st }}$ and $2^{\text {nd }}$ seasons, respectively followed by arabic gum at 5\%. On the other hand the lowest values in this respect were recorded in case of control treatment.

\section{Sensory Evaluation}

Sensory evaluation of coated and uncoated fruit at the end of the storage period revealed significant differences in pulp colour, texture, flavour and overall acceptability (Table 10). Cherry tomato fruits which coated with arabic gum at $10 \%$ or $5 \%$ were the most effective treatments which gave the highest scores in all parameters after 40 days of storage, while those coated with xanthan and cellulose developed poor pulp colour and inferior texture and had off-flavours. The latter fruits which not acceptable to the panel of experts were untreated fruits compared with $5 \%$ or $10 \%$ arabic gum, control fruit and fruit treated with xanthan had lower scores for flavour and overall acceptability. These results suggest that arabic gum up to $10 \%$ can be used successfully as an edible coating for prolonging the storage period and improving tomato fruit quality during storage. Similar results were observed by Ali $\boldsymbol{e t}$ al. (2010) when they treated tomato fruits with arabic gum coating.

\section{Effect of Some Edible Coating Materials Treatments on Linear Growth of $B$. cinerea and A. alternata In vitro}

In vitro study results varied according to the type of treatment, and its concentration as shown in Table 11. The results showed that linear growth of $B$. cinerea and A. alternata in vitro for tomato fruits were significantly by different tested materials as compared with control 
Table 9. Effect of some edible coating materials on dry matter percentage of cherry tomato fruits during cold storage in 2018 and 2019 seasons

\begin{tabular}{|c|c|c|c|c|c|c|c|c|c|c|c|}
\hline \multirow[t]{4}{*}{$\begin{array}{l}\text { Treatment (T) } \\
\text { (T) }\end{array}$} & \multicolumn{11}{|c|}{ Dry matter (\%) } \\
\hline & \multicolumn{6}{|c|}{2018 season } & \multicolumn{5}{|c|}{2019 season } \\
\hline & \multicolumn{11}{|c|}{ Storage period in day $(\mathbf{S})$} \\
\hline & $\mathbf{0}$ & 10 & 20 & 30 & 40 & Mean & $\mathbf{0}$ & 10 & $20 \quad 30$ & 40 & Mean \\
\hline Control & 9.50 & 8.00 & 7.50 & 7.00 & 6.67 & 7.73 & 9.75 & 8.45 & 8.007 .36 & 6.50 & 8.01 \\
\hline Arabic gum at 5\% & 9.50 & 9.15 & 9.13 & 8.50 & 8.00 & 8.85 & 9.75 & 9.48 & 9.188 .80 & 8.22 & 9.08 \\
\hline Arabic gum at $10 \%$ & 9.50 & 9.24 & 9.12 & 8.61 & 8.24 & 8.94 & 9.75 & 9.53 & 9.128 .86 & 8.43 & 9.14 \\
\hline Cellulose at $1 \%$ & 9.50 & 8.85 & 8.43 & 7.83 & 7.33 & 8.39 & 9.75 & 8.80 & 8.418 .00 & 7.37 & 8.46 \\
\hline Cellulose at $2 \%$ & 9.50 & 9.00 & 8.65 & 8.00 & 7.50 & 8.53 & 9.75 & 8.83 & 8.648 .30 & 7.60 & 8.62 \\
\hline Pectin at $1 \%$ & 9.50 & 9.00 & 8.80 & 8.14 & 7.74 & 8.63 & 9.75 & 9.00 & 8.858 .43 & 7.81 & 8.77 \\
\hline Pectin at $2 \%$ & 9.50 & 9.12 & 8.93 & 8.33 & 7.87 & 8.75 & 9.75 & 9.32 & 9.198 .75 & 8.00 & 9.00 \\
\hline Xanthan at $0.5 \%$ & 9.50 & 8.33 & 7.80 & 7.60 & 7.45 & 8.13 & 9.75 & 8.61 & 8.308 .00 & 7.00 & 8.33 \\
\hline Xanthan at $1 \%$ & 9.50 & 8.48 & 8.00 & 7.75 & 7.60 & 8.26 & 9.75 & 8.50 & 8.227 .50 & 6.85 & 8.16 \\
\hline Mean (S) & 9.50 & 8.79 & 8.48 & 7.97 & 7.60 & - & 9.75 & 8.94 & 8.658 .22 & 7.53 & - \\
\hline LSD at 0.05 level & \multicolumn{2}{|c|}{$\mathrm{T}=0.02$} & \multicolumn{2}{|c|}{$S=0.02$} & \multicolumn{2}{|c|}{$\mathrm{T} \times \mathrm{S}=0.06$} & \multicolumn{2}{|c|}{$\mathrm{T}=0.02$} & $S=0.02$ & \multicolumn{2}{|c|}{$\mathrm{T} \times \mathrm{S}=0.07$} \\
\hline
\end{tabular}

Table 10. Effect of some edible coating materials on sensory evaluation of cherry tomato fruit at 40 days after storage in 2019 season

\begin{tabular}{lcccc}
\hline Treatment (T) & Pulp colour & Flavour & Texture & Overall acceptability \\
\hline Control & 6.0 & 5.0 & 5.0 & 6.0 \\
Arabic gum at 5\% & 9.0 & 8.0 & 9.0 & 9.0 \\
Arabic gum at 10\% & 9.0 & 8.0 & 9.0 & 9.0 \\
Cellulose at 1\% & 7.0 & 6.0 & 7.0 & 7.0 \\
Cellulose at 2\% & 8.0 & 7.0 & 8.0 & 8.0 \\
Pectin at 1\% & 8.0 & 7.0 & 8.0 & 8.0 \\
Pectin at 2\% & 8.0 & 7.0 & 9.0 & 9.0 \\
Xanthan at 0.5\% & 7.0 & 6.0 & 6.0 & 7.0 \\
Xanthan at 1\% & 7.0 & 6.0 & 7.0 & 7.0 \\
LSD at 0.05 level & 1.0 & 1.1 & 1.2 & 1.1 \\
\hline
\end{tabular}


Table 11. Effect of some edible coating materials on linear growth of A. alternata and B. cinerea in vitro in 2018 and 2019 seasons

\begin{tabular}{|c|c|c|c|c|c|c|c|c|}
\hline \multirow[t]{3}{*}{ Treatment (T) } & \multicolumn{4}{|c|}{2018 season } & \multicolumn{4}{|c|}{2019 season } \\
\hline & \multicolumn{2}{|c|}{ A.alternata } & \multicolumn{2}{|c|}{ B.cinerea } & \multicolumn{2}{|c|}{ A.alternata } & \multicolumn{2}{|c|}{ B.cinerea } \\
\hline & $\begin{array}{c}\text { Linear } \\
\text { growth } \\
(\mathbf{m m})\end{array}$ & Inhibition & $\begin{array}{c}\text { Linear } \\
\text { growth } \\
(\mathrm{mm})\end{array}$ & Inhibition & $\begin{array}{c}\text { Linear } \\
\text { growth } \\
(\mathbf{m m})\end{array}$ & Inhibition & $\begin{array}{c}\text { Linear } \\
\text { growth } \\
(\mathbf{m m})\end{array}$ & Inhibition \\
\hline Control & 81.00 & 00.00 & 90.00 & 00.00 & 84.00 & 00.00 & 91.00 & 00.00 \\
\hline Arabic gum at $5 \%$ & 11.11 & 86.28 & 12.22 & 86.42 & 11.18 & 86.69 & 12.79 & 85.94 \\
\hline Arabic gum at $10 \%$ & 7.25 & 91.05 & 10.32 & 88.53 & 7.86 & 90.64 & 10.86 & 88.06 \\
\hline Cellulose at $1 \%$ & 35.80 & 55.80 & 33.33 & 62.97 & 36.04 & 57.09 & 29.12 & 61.74 \\
\hline Cellulose at $2 \%$ & 29.62 & 63.43 & 28.88 & 67.91 & 29.97 & 64.53 & 38.27 & 68.00 \\
\hline Pectin at $1 \%$ & 13.58 & 83.23 & 15.55 & 82.72 & 14.09 & 83.22 & 14.98 & 83.54 \\
\hline Pectin at $2 \%$ & 8.44 & 89.58 & 9.51 & 89.43 & 8.78 & 89.54 & 11.81 & 87.02 \\
\hline Xanthan at $0.5 \%$ & 38.27 & 52.75 & 37.77 & 58.03 & 38.60 & 50.04 & 38.27 & 57.94 \\
\hline Xanthan at $1 \%$ & 34.26 & 57.33 & 34.44 & 61.73 & 35.04 & 58.28 & 35.42 & 61.07 \\
\hline LSD at 0.05 level & 4.06 & 7.04 & 2.36 & 7.65 & 3.16 & 3.41 & 1.77 & 2.88 \\
\hline
\end{tabular}

treatment. Arabic gum at $10 \%$ was the most effective treatment completely suppressed fungal growth followed by arabic gum at $5 \%$ without significant differences between them, while the other treatments were less effect in this concern. The least treatments efficiency was observed in case of control treatment. The antibacterial and antifungal potential of arabic gum is due to it is high terpene contents. Terpenes are biologically active molecules and are considered to be part of plants defense systems and as such have been included in the large group of protective molecules found in plants named as phytoprotectants (Morrissey and Osbourn, 1999). It was concluded that, arabic gum at $10 \%$ or $5 \%$ may help in controlling $B$. cinerea and A. alternata infection on cherry tomato in vivo.

\section{Effect of Some Edible Coating Materials Treatments on Disease Severity in Artificially and Naturally Infected Fruits}

As shown in Table 12 cherry tomatoes treated with $10 \%$ arabic gum did not show any sign of fungal decay after a storage period of 40 days at $13^{\circ} \mathrm{C}$ and $90 \% \mathrm{RH}$. Treating cherry tomatoes with arabic gum at $10 \%$ strongly suppressed $B$. cinerea and $A$. alternata development in either artificially - inoculated and naturally infected cherry tomatoes. These results are in agreement with Bnuyan et al. (2015) who stated that arabic gum play a role in plant defence mechanisms against phytopathogenic microorganisms. The used arabic gum significantly minimized microbial counts in preservative solution especially when arabic gum was added to preservative solution at $10 \%$. A majority of the described antimicrobial effect of arabic gum have been attributed to their secondary metabolites or due to presence of saponin, saponin glycosides, volatile oil, hydrolysable tannin, triterpenoid, flavonoids, phenol and alkaloids (Morrissey and Osbourn, 1999). Arabic gum at concentration of $5 \%$ was also effective in reducing disease incidence by $B$. cinerea and A .alternata.

Such effects of arabic gum are attributed to the high salt content of $\mathrm{Ca}^{+2}, \mathrm{Mg}^{+2}$ and $\mathrm{K}^{+2}$ of polysaccharides in $\mathrm{AG}$, and the effect of gum in the metabolism of $\mathrm{Ca}$ and possibly phosphate. It is also known that cyanogenic glycosides and AG contains many types of enzymes such as oxidases, peroxidases, and pectinases, some of which have antimicrobial properties (Tyler $\boldsymbol{e t}$ al., 1977; Saini et al., 2008). 
Table 12. Effect of some edible coating materials on disease severity of artificially and naturally infected cherry tomato fruits at the end of storage (40days) in 2018 and 2019 seasons

\begin{tabular}{|c|c|c|c|c|c|c|c|c|c|}
\hline \multirow{3}{*}{$\begin{array}{l}\text { Edible coating } \\
\text { treatments }\end{array}$} & \multirow[t]{3}{*}{ Fungi } & \multicolumn{8}{|c|}{ Disease severity (\%) } \\
\hline & & \multicolumn{4}{|c|}{2018 season } & \multicolumn{4}{|c|}{2019 season } \\
\hline & & $\mathbf{A I}$ & $\begin{array}{c}\text { Efficiency } \\
(\%)\end{array}$ & NI & $\begin{array}{c}\text { Efficiency } \\
(\%)\end{array}$ & AI & $\begin{array}{c}\text { Efficiency } \\
(\%)\end{array}$ & NI & $\begin{array}{c}\text { Efficiency } \\
(\%)\end{array}$ \\
\hline \multirow{2}{*}{ Control } & A. alternata & 39.90 & 00.00 & 10.38 & 00.00 & 41.38 & 00.00 & 11.56 & 00.00 \\
\hline & B. cinerea & 48.13 & 00.00 & 15.32 & 00.00 & 52.50 & 00.00 & 18.75 & 00.00 \\
\hline \multirow{2}{*}{ Arabic gum at $5 \%$} & A. alternata & 3.75 & 90.60 & 0.82 & 92.10 & 2.79 & 93.25 & 0.88 & 92.38 \\
\hline & B. cinerea & 3.10 & 93.56 & 0.80 & 94.78 & 3.64 & 93.06 & 0.82 & 95.62 \\
\hline \multirow{2}{*}{ Arabic gum at $10 \%$} & A. alternata & 3.30 & 91.73 & 0.00 & 100.0 & 2.15 & 94.80 & 0.00 & 100.0 \\
\hline & B. cinerea & 2.85 & 94.08 & 0.00 & 100.0 & 3.04 & 94.21 & 0.00 & 100.0 \\
\hline \multirow{2}{*}{ Cellulose at $1 \%$} & A. alternata & 4.76 & 88.07 & 1.25 & 87.95 & 4.25 & 89.73 & 1.25 & 89.18 \\
\hline & B. cinerea & 5.13 & 89.34 & 1.34 & 91.25 & 5.51 & 89.50 & 1.15 & 93.86 \\
\hline \multirow{2}{*}{ Cellulose at $2 \%$} & A. alternata & 4.14 & 89.62 & 0.96 & 90.75 & 3.51 & 91.52 & 0.96 & 91.69 \\
\hline & B. cinerea & 4.81 & 90.00 & 1.00 & 93.47 & 5.23 & 90.04 & 0.98 & 94.77 \\
\hline \multirow{2}{*}{ Pectin at $1 \%$} & A. alternata & 12.78 & 67.96 & 6.25 & 39.78 & 11.93 & 71.16 & 6.25 & 45.93 \\
\hline & B. cinerea & 15.41 & 67.98 & 6.12 & 60.05 & 16.17 & 69.20 & 5.85 & 68.80 \\
\hline \multirow{2}{*}{ Pectin at $2 \%$} & A. alternata & 10.57 & 73.51 & 6.25 & 39.78 & 9.89 & 76.10 & 6.25 & 45.93 \\
\hline & B. cinerea & 14.69 & 69.48 & 6.45 & 57.90 & 15.33 & 70.80 & 5.98 & 68.10 \\
\hline \multirow{2}{*}{ Xanthan at $0.5 \%$} & A. alternata & 13.67 & 65.74 & 7.34 & 29.28 & 11.06 & 73.27 & 7.51 & 35.03 \\
\hline & B. cinerea & 18.13 & 62.33 & 6.91 & 54.89 & 17.47 & 66.72 & 6.45 & 65.60 \\
\hline \multirow{2}{*}{ Xanthan at $1 \%$} & A. alternata & 12.34 & 69.07 & 7.85 & 24.37 & 11.23 & 72.86 & 7.79 & 32.61 \\
\hline & B. cinerea & 20.00 & 58.44 & 7.38 & 51.82 & 18.15 & 65.42 & 7.54 & 59.78 \\
\hline \multirow{2}{*}{ LSD at 0.05 level } & A. alternata & 0.77 & 2.04 & 0.29 & 1.94 & 0.46 & 1.13 & 0.34 & 2.13 \\
\hline & B. cinerea & 1.41 & 3.01 & 0.50 & 1.80 & 1.94 & 3.41 & 0.86 & 2.18 \\
\hline
\end{tabular}

$\mathrm{AI}=$ Artificially Infection $\mathrm{NI}=$ Naturally Infection

\section{Conclusion}

From the previous results, it could be concluded that, tomato fruit coated with $10 \%$ or $5 \%$ arabic gum showed a significant delay in the change of weight, general appearance, firmness, total soluble solids, titratable acidity, lycopene concentration, $\mathrm{pH}$ values, vitamin $\mathrm{C}$. amount and dry matter percentage during storage at $13^{\circ} \mathrm{C}$ and $90-95 \% \mathrm{RH}$ as compared to uncoated control fruit or other treatments. In addition, sensory evaluation showed that $10 \%$ or $5 \%$ arabic gum coating maintained the overall quality of the tomato fruits during storage, meanwhile pathogen measurements showed that arabic gum is considered potent antimicrobial agent.

\section{REFERENCES}

Abdullah, M.A.A. and H.A. Ibrahim (2018). Effect of fumaric acid, $\beta$-aminobutyric acid and packaging materials treatments on quality and storability of cherry tomatoes. Middle East J. Agric. Res., 7 (4): 1395-1410.

Abebe, Z., B.T. Yetenayet and A. Mohammed (2017). Effects of edible coating materials and stages of maturity at harvest on storage life and quality of tomato (Lycopersicon esculentum Mill.) fruits. Afr. J. Agric. Res., 12 (8): 550-565.

Ali, A., M. Maqbool, P.G. Alderson and N. Zahid (2013). Effect of gum arabic as an edible coating on antioxidant capacity of 
tomato (Solanum lycopersicum L.) fruit during storage. Postharvest Biol. and Technol., 76: 119-124.

Ali, A., M. Maqbool, S. Ramachandran and P.G. Alderson (2010). Gum arabic as a novel edible coating for enhancing shelf life and improving postharvest quality of tomato (Solanum lycopersicum L.) fruit. Postharvest Biol. and Technol., 58 : 42-47.

Anderson, D., J. Millar and W. Weiping (1991). Gum arabic (Acacia senegal): unambiguous identification by 13 C-NMR spectroscopy as an adjunct to the revised jecfa specification, and the application of 13 CNMR spectra for regulatory/ legislative pumposed. Food Additives and Contaminants, 8:405-421.

AOAC (2000). Official Methods of Analysis of AOAC International. $17^{\text {th }}$ Ed. Gaithersburg, MD, USA, Association of Analytical Communities.

Bai, J.V.A., R.D. Hagenmaier, J.P. Mattheis and E.A. Baldwin (2003). Formulation of zein coatings for apple (Malus domestica Borkh). Postharvest Biol. Technol., 28:259-268.

Baldwin, E.A., J.K. Burns, W. Kazokas, J.K. Brecht, R.D. Hagenmaier, R.J. Bender and E. Pesis (1999). Effect of two edible coatings with different permeability characteristics on mango (Mangifera indica L.) ripening during storage. Postharvest Biol. Technol., 17: 215-226.

Bnuyan, I. A., N.K. Hindi, M.H. Jebur and M.A. Mahdi (2015). In vitro antimicrobial activity of gum arabic (Al Manna and Tayebat) prebiotics against infectious pathogens. Ijppr. Human, 3 (3): 77-85.

Causse, M., M. Buret, K. Robini and P. Verschave (2003). Inheritance of nutritional and sensory quality traits in fresh market tomato and relation to consumer preferences. J. Food Sci., 68 (7): 2342-2350.

El-Anany, A. M., G. F. A. Hassan and F. M. Rehab Ali (2009). Effects of edible coatings on the shelif-life and quality of Anna apple (Malus domestica Borkh) during cold storage. J. Food Technol., 7:5-11.

El-Ramady, H.R., E. Domokos-Szabolcsy, A.A. Neama, S.T. 'Hussein and F. Miklos (2015). Postharvest Management of Fruits and
Vegetables Storage, in Sustainable Agriculture Reviews, Lichtfouse, Switzerland, 65-152,

Felix, Delina, E. and T. Mahendran (2009). Physico-Chemical properties of mature green tomatoes (Lycopersicon esculentum) coated with pectin during storage and ripening. Tropical Agric. Res. and Ext., 12 (2): 110-112.

Fokemma, N.J. (1973). The role of saprophytic fungi in antagonism against Drechslera sorokiniana (Helminthosporium sativum) on agar plates and on rye leaves with pollen. Physiol. Plant Pathol., 3: 195-205.

Gad, M.M. and O.A. Zagzog (2017). Mixing xanthan gum and chitosan nano particles to form new coating for maintaining storage life and quality of Elmamoura guava fruits. Int. J. Curr. Microbiol. App. Sci., 6 (11): 1582-1593.

Gonzalez-Aguilar, A., L. Cruz, R. Granados, M. Baez and R. Saltveit (1997). Hot water dips and film packaging extend the self-life of bell peppers. Post-Harvest Hort. Series-Dept. Pomol. Univ. California, 18: 66- 72.

Hong, K., J. Xie, L. Zhang, D. Sun, and D. Gong (2012). "Effects of chitosan coating on postharvest life and quality of guava (Psidium guajava L.) fruit during cold storage. Scientia Hort., 144: 172-178.

Ibrahim, H.A. and M.A.A. Abdullah (2018). Effects of 1-Methylcyclopropane on quality of tomato and sweet pepper fruits during mixed loads. Biosci. Res., 15(1): 270-279.

Ilahy, R., C. Hdider, MS. Lenucci, I. Tlili and G. Dalessandro (2011). Antioxidant activity and bioactive compound changes during fruit ripening high-lycopene tomato cultivars. J. Food Comp. Anal., 24:588-595.

Isela, R.G., C.V.M. Reynaldo, A.S.E. Brenda, A.G.A. Gustavo, M. Edgar, G.P.M. Melissa, R.T.R. Melvin, A.O.R. Luis and A.Z.J. Fernando (2016). Oregano (Lippia graveolens) essential oil added within pectin edible coatings prevents fungal decay and increases the antioxidant capacity of treated tomatoes. J. Sci. Food and Technol., 96: 1 -7.

Javanmardi, J., and C. Kubota (2006). Variation of lycopene, antioxidant activity, total soluble solids and weight loss of tomato 
during postharvest storage. Postharvest Biol. and Technol., 41:151-155.

Kowalczyk, K. and J. Gajc-Wolska (2011). Effect of the kind of growing medium and transplant grafting on the cherry tomato yielding. Acta. Sci. Polonorum, Hortorum Cultus., 10 (1):61-70.

Mirdehghan, S.H., M. Rahemi, D. MartinezRomero, F. Guillen, J.M. Valverde, P.J. Zapata, M. Serrano and D. Valero (2007). Reduction of pomegranate chilling injury storage after heattreatment: role of polyamines. Post harvest Biol. and Technol., 44: 19-25.

Morcos, J.F. (1984). Studies on rots of pom fruits in ARE, M.Sc. Thesis, Fac. Agric., Cairo Univ., Egypt, 133.

Morrissey, J.P. and A.E. Osbourn (1999). Fungal resistance to plant antibiotics as a mechanism of pathogenesis. Microbial Med. Biol. Rev., 63: 708-724.

Nabi, S.U., W.H. Raja, K.L. Kumawat, J.I. Mir, O.C. Sharma, D.B. Singh and M.A. Sheikh (2017). Post harvest diseases of temperate fruits and their management strategies-A Review. Int. J. Pure App. Biosci., 5 (3): 885898.

Paradis, C., F. Castaigne, T. Desrosiers and C. Willemot (1995). Evaluation of vitamin C, B-carotene and chlorophyll content in broccoli heads and florets during storage in air. Sci. des Aliments, 15 (2): 113-123.

Quoc, L.P.T., D.P. Hoa, H.T.B. Ngoc and T.T.Y. Phi (2015). Effect of xanthan gum solution on the preservation of acerola (Malpighia glabra L.) Cercetari Agron. in Moldova, 48 (3): 89-97.

Raafat, S.M., M.I. Abou-Zaid, M.R. Tohamy and H.E. Arisha (2016). Impact of some plant essential oil treatments on controlling cherry tomatoes spoilage, improvement shelf life and quality attributes during storage. Zagazig J. Agric. Res., 43 (3): 785-813.

Ranganna, S. (1979). Manual of analysis of fruits and vegetables products. Tata Mc Craw-Hill publishing company limited, New Delhi., 173.
Ruelas-Chacon, X., J.C. Contreras-Esquivel, J. Montañez, A.F. Aguilera-Carbo, M.L. ReyesVega, R.D. Peralta-Rodriguez and G. Sanchéz-Brambila (2017). Guar gum as an edible coating for enhancing shelf-life and improving postharvest quality of Roma tomato (Solanum lycopersicum L.). J. Food Quality, 1-9.

Saini, M., R. Saini, S. Roy and A. Kumar (2008). Comparative pharmacognostical and antimicrobial studies of Acacia species (Mimosaceae). J. Med. Plant Res., 2 (12): 378-386.

Sakaldas, M. and K. Kaynas (2010). Biochemical and quality changes of green sweet bell pepper as affected by different postharvest treatments. Afr. J. Biotech., 9 (48): 81748181.

Sanchez-Gonz, L., A.C. Pastor, M. Vargas, A. Chiralt, C. Gonzalez-Martınez and C. Chafer (2011). Effect of hydroxypropy-'1methyl cellulose and chitosan coatings with and without bergamot essential oil on quality and safety of cold stored grapes. Postharvest Biol. and Technol., 60: 57-63.

Sharma, B.R., L. Naresh, N.C. Dhuldhoya, S.U. Merchant and U.C. Merchant (2006). Xanthan Gum- A Boon to Food Industry. Food Promotion Chronicle, 1 (5): 27-30.

Snedecor, G.W. and W.G. Cochrane (1989). Statistical Methodes. $7^{\text {th }}$ Ed., Iowa State Univ. Press. Ames. Iowa, USA, 395.

Tyler, V., L. Brady and J. Robbers (1977). $7^{\text {th }}$ Ed. Phuladelphia Lea and Febiger, 66-68.

Valencia-Chamorro, S.A., M.B. Perez-Gago, M.A. Del Rio and L. Palou (2010). Effect of antifungal hydroxypropyl methylcelluloselipid edible composite coatings on penicillium decay development and postharvest quality of cold-stored "ortanique" mandarins. J. Food Sci., 75 (8) : S418-S426.

Wills, H.H.R., T.H. Lee, D. Graham, W.B. Mc Glasson and E.G. Hall (1981). An introduction in the physiology and handling of fruits and vegetables. New South Wales Univ. Prees Limited Australia, 123-126. 
تأثير بعض الأغثية الصالحة للأكل على جودة ثمار الطماطم الثيرى والإصابة بأعفان الثمار أثناء

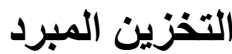

$$
\begin{aligned}
& \text { أميمه عثمان محمد1 ـ ممدوح بسيونى عزازى2 ـ سميرالسيد على بلوى } 3 \\
& \text { 1- قسم بحوث تداول الخضر - معهد بحوث البساتين - مركز البحوث الزر اعية ـ مصر }
\end{aligned}
$$

2- قسم بحوث تكنولوجيا تصنيع الحاصلات البستانيةـ معهد بحوث تكنولوجيا الأغذية ـ مركز البحوث الزر اعية ـ مصر

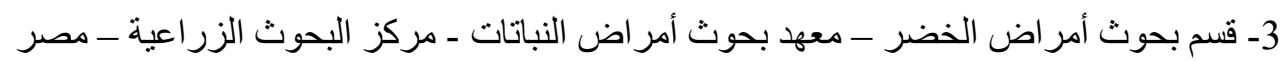

أجريت هذه الدراسة خلال موسمى 2018، 2019 على الدى الطماطم الثيرى هجين الجيل الأول شيريوبينو والتى تم

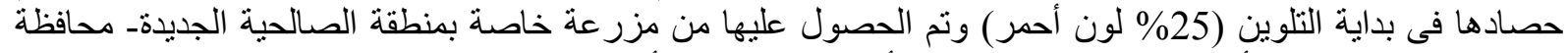

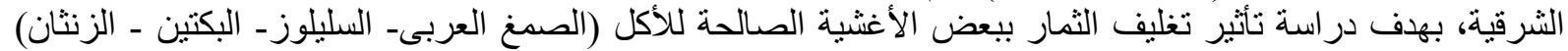

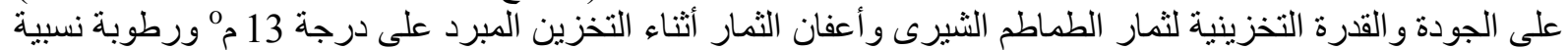

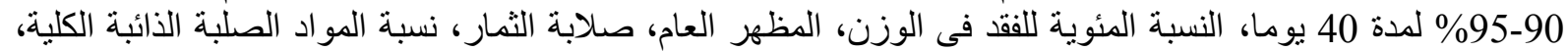

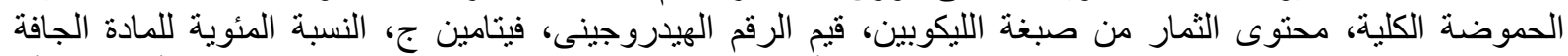

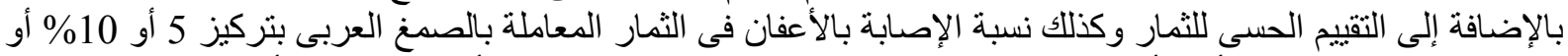

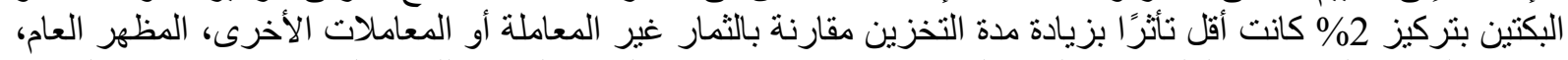

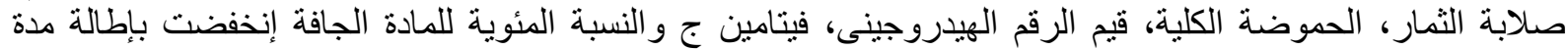

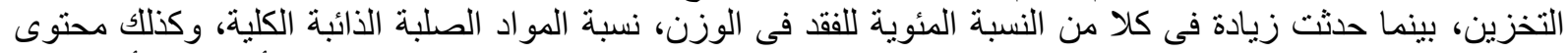

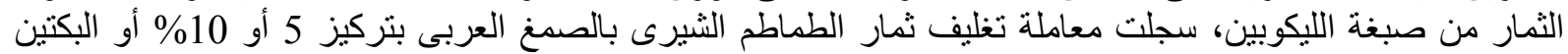

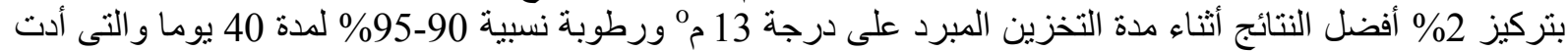

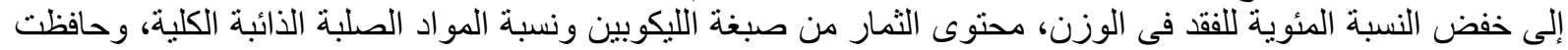

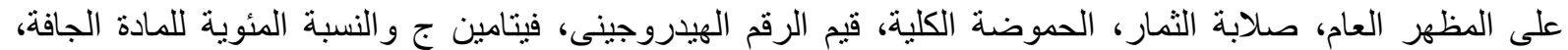

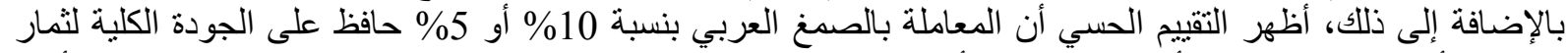

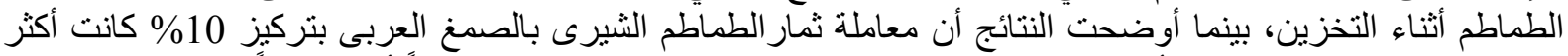

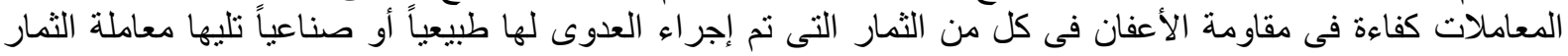

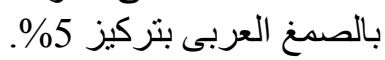

أستاذ الخضر المتفرغ - معهد بحوث البساتين - مركز البحوث الزر اعية. 